\title{
Hubungan Perilaku Diet Dengan Massa Lemak Tubuh Pada Remaja Putri Di SMA Negeri 5 Surabaya
}

\section{The Correlation of Dieting Behavior with Body Fat Mass of Adolescent Girls at Senior High School 5 Surabaya}

\author{
Winda Kusumawardani*, Farapt
}

\begin{abstract}
ABSTRAK
Latar Belakang: Peningkatan massa lemak tubuh biasa dialami oleh remaja putri. Massa lemak tubuh yang berlebih akan berdampak pada status gizi serta bentuk tubuh. Diet merupakan salah satu cara untuk menurunkan massa lemak tubuh tersebut agar bentuk tubuh menjadi ideal.

Tujuan:menganalisis hubungan antara perilaku diet dengan massa lemak tubuh remaja putri di SMA Negeri 5 Surabaya.

Metode: Penelitian ini menggunakan desain studi cross sectional dan melibatkan 76 responden yang dipilih secara simple random sampling. Data dikumpulkan dengan melakukan pengukuran berat badan dan tinggi badan untuk menilai status gizi serta pengukuran persentase massa lemak tubuh menggunakan BIA (Bioelectrical Impedance Analysis). Wawancara dan pengisian kuesioner untuk mengetahui karakteristik dan perilaku diet responden. Teknik analisis data yang digunakan adalah uji korelasi chi-square dengan $\mathrm{p}<0,05$.

Hasil: rata-rata usia subyek $15,93 \pm 0,64$ tahun dengan rerata besar uang saku harian sebesar Rp $22.474 \pm 12.62 \mathrm{i}$, Aktivitas fisik tingkat ringan sebanyak $42,1 \%$ siswi, dan status gizi responden berdasarkan IMT/U didominasi oleh kategori normal sebanyak $80,3 \%$. Sebagian besar responden menjalankan diet sehat sebanyak $61,8 \%$ dengan rata-rata nilai sebesar 39,8 .Sebanyak $31,6 \%$ subyek dengan kategori massa lebih lebihHasil analisis menunjukkan tidak adanya hubungan antara perilaku diet dengan persen lemak tubuh remaja putri $(p>0,06)$.

Kesimpulan: Perilaku diet tidak memiliki hubungan yang bermakna dengan massa lemak tubuh remaja putri. Diperlukan penelitian lebih lanjut untuk menganalisis faktor lain yang berhubungan dengan perilaku diet dan massa lemak tubuh pada remaja putri.
\end{abstract}

Kata kunci: remaja, perilaku diet, massa lemak tubuh

\section{ABSTRACT}

Background: The fat body mass can be increased especially in adolescent girl. When fat body mass increased it can affect the nutritional status and body image. If someone wants to have the ideal body imaged, they can try to do diet to decreased fat body mass.

Objectives: This study aimed to analyze a relationship of dieting behavior with fat body mass at SMA Negeri 5 Surabaya. Methods: The design of the study was cross sectional involving 76 selected samples in the simple random sampling. The aimed of measuring body height, weight and body fat mass for scoring the nutritional status and percentage of fat body mass. Some characteristic of the respondents were age, amount of pocket money, physical activity and nutritional status. The data were analyzed by using Chi-Square correlation test with $p<0.05$.

Results: The averaged of respondents age was 16 years old, most of all the amounted of pocket money from the respondents approximately IDR 25,000-75,000 (35.5\%). The category of physical activity was mild (42.1\%), and the nutritional status of respondents was normal (61.3\%). Some of the respondents was doing a healthy diet (61.8\%) with averaged score was 39.8. The averaged of body fat mass from the respondents was $25.24 \%$. The result showing there was no relationship between diet behavior with fat body mass in girl adolescent $(p>0.060)$.

Conclusions: Diet behavior was not founded to be related to the fat body mass in female adolescent. Therefore the students needed to get more information about dieting behavior and fat body mass to prevented more nutritional problems.

Keywords: adolescent, dieting behavior, fat body mass 


\author{
*Koresponden: \\ Winda Kusumawardani \\ windakusumawardanii@gmail.com \\ Departemen Gizi Kesehatan, Fakultas Kesehatan Masyarakat, Universitas Airlangga
}

\section{PENDAHULUAN}

Remaja merupakan periode transisi yang penting dari masa anak-anak menuju dewasa, masa pencarian jati diri atau identitas diri dan masa munculnya perubahan fisik $^{1}$. Remaja putri cenderung lebih sensitif terhadap perkembangan fisik baik dari keadaan dan bentuk tubuh dibandingkan remaja putra. Hal tersebut dikarenakan remaja putri mengalami peningkatan massa lemak tubuh yang menyebabkan kondisi dan bentuk tubuh tidak ideal, sedangkan pada remaja putra mengalami peningkatan massa otot ${ }^{2}$. Apabila peningkatan massa lemak tersebut tidak mendapat perhatian khusus, maka status gizi remaja akan menjadi berlebih baik overweight hingga obesitas. Berdasarkan data WHO di tahun 2016, terdapat $18 \%$ anak dan remaja dengan rentang usia 5-19 tahun mengalami overweight ${ }^{3}$. Hasil pada NHANES tahun 20012004 di United States dan 2009-2012 di Canada, adanya peningkatan prevalensi gizi lebih pada anak dan remaja dengan usia 2-19 tahun sebesar $16,6 \%$ menjadi $17,5 \%$ di United States dan sebesar $12,4 \%$ menjadi $13 \%$ di Canada ${ }^{4}$. Data dari Riskesdas tahun 2010 dan 2013 memperlihatkan adanya peningkatan prevalensi gizi lebih pada remaja dari $1,4 \%$ menjadi $7,3 \%^{5,6}$. Prevalensi gizi lebih di Jawa Timur pada tahun 2016 sebesar 11,16\% dimana angka tersebut melebihi dari angka prevalensi nasional ${ }^{7}$.

Perilaku diet lebih diminati oleh kalangan remaja putri guna mengontrol atau menurunkan berat badan dikarenakan diet tidak membutuhkan biaya berlebih, tidak berpantangan dengan lingkungan sosial, serta tidak menimbulkan efek samping yang langsung dirasakan $^{8}$. Remaja putri usia 17 tahun ditemukan lebih sering melakukan diet dibanding remaja laki-laki. Sebagian besar remaja putri merasa gemuk dan memiliki tubuh yang kurang ideal sehingga dilakukan diet guna memiliki tubuh yang ideal ${ }^{9}$. Interpretasi diet tiap individu berbeda-beda dan bervariasi, ada yang menggunakan cara sehat dan tidak sehat. Prinsip diet sehat adalah mengatur asupan harian sesuai kebutuhan tubuh serta meningkatkan aktivitas fisik. Sedangkan prinsip tidak sehat adalah dengan mengurangi asupan makanan secara drastis, melewatkan waktu makan dan penggunaan produk obat-obatan seperti obat penurun berat badan dan obat pencahar ${ }^{10}$. Untuk mendapatkan hasil yang cepat, diet tidak sehat yang sering dipilih oleh sebagian besar orang dibandingkan diet sehat. Dengan menjalankan diet tidak sehat, asupan zat gizi makro yang masuk dalam tubuh akan mengalami kekurangan atau defisit. Pada saat kondisi kelaparan, lambung memproduksi hormon ghrelin. Hormon ghrelin berguna untuk memberikan informasi pada hipotalamus terkait kondisi tubuh yang sedang mengalami kelaparan atau kekurangan energi akan tetapi tidak mendapat respon dari luar tubuh. Pada akhirnya tubuh segera memenuhi respon tersebut dengan cara pemecahan (lipolisis) simpanan lemak dalam tubuh dan pembentukan glukosa baru (glukoneogenesis) guna memenuhi kebutuhan energi ${ }^{11}$. Dengan adanya penggunaan simpanan lemak, secara tidak langsung massa lemak tubuh berkurang dan mengalami penurunan berat badan ${ }^{12}$.

Penelitian terkait perilaku diet pada remaja belum banyak dilakukan khususnya di Kota Surabaya serta belum banyak artikel yang membahas kaitannya dengan massa lemak tubuh. Penelitian ini bertujuan untuk menganalisis hubungan perilaku diet dengan massa lemak tubuh pada remaja putri di SMA Negeri 5 Surabaya. Lokasi ini dipilih karena merupakan salah satu sekolah menegah atas yang berada di pusat Kota Surabaya dan memiliki prevalensi remaja gizi lebih (overweight dan obese) yang lebih tinggi dari tingkat provinsi dan nasional, yang tidak menutup kemungkinan sebagian remaja putri tersebut melakukan diet. Sehingga perlu dilakukan penelitian pada remaja putri terkait perilaku diet.

\section{METODE}

Penelitian ini menggunakan desain studi potong lintang (cross sectional). Total populasi sebanyak 364 siswi yang kemudian dihitung menggunakan rumus proporsi binomunal. Teknik pengambilan sampel menggunakan simple random sampling dengan jumlah sampel 76 siswi. Kriteria inklusi responden pada penelitian ini adalah siswi kelas $X$ dan XI SMA Negeri 5 Surabaya, dalam keadaan sehat, dan bersedia mengikuti penelitian.

Variabel bebas pada penelitian ini adalah usia, besar uang saku harian, aktivitas fisik, status gizi, dan perilaku diet sedangkan variabel terikat yaitu massa lemak tubuh. Pengambilan data dilakukan dengan pengisian kuesioner data identitas untuk mengetahui usia dan besar uang saku harian, pengisian kuesioner IPAQ untuk mengetahui tingkat aktivitas fisik, mengukur tinggi badan dan berat badan menggunakan microtoise dan timbangan digital pada BIA untuk mendapatkan status gizi berdasarkan IMT/U, serta mengukur massa lemak tubuh responden menggunakan Bioelectrical Impedance Analysis (BIA) untuk mendapatkan persentase massa lemak tubuh. Tingkat aktivitas fisik dibagi menjadi 3 kategori yaitu ringan $1<600$ $\mathrm{METs} / \mathrm{minggu})$, sedang (600-2999 METs/minggu), dan berat ( $\geq 3000 \mathrm{METs} /$ minggu). Status gizi responden dilihat berdasarkan indikator IMT/U menurut Kemenkes tahun 2010 yang terbagi menjadi 5 kategori yaitu sangat kurus (<-3SD), kurus (-3SD sampai dengan <-2SD), normal (-2SD sampai dengan 1SD), gemuk ( $>1 S D$ sampai dengan 2SD), dan obesitas $(>2 S D)^{13}$. Perilaku diet responden dikategorikan menjadi diet sehat (nilai $>38$ ) dan diet tidak sehat (nilai $\leq 38$ ). Kuesioner perilaku diet dikembangkan oleh Vivi Sundari yang sudah tervalidasi ${ }^{14}$. Terdapat 15 pernyataan pada kuesioner perilaku diet yang menggunakan penilaian skala Likert dengan 
pernyataan positif. Pernyataan positif memiliki nilai 1 untuk pilihan TP (Tidak Pernah), 2 untuk pilihan KD (Kadang-Kadang), 3 untuk pilihan SR (Sering), dan 4 untuk pilihan SL (Selalu). Berdasarkan penilaian tersebut, didapatkan nilai terendah sebesar 15 dan tertinggi sebesar 60 . Rentang antara nilai tertinggi dan terendah yaitu 45 yang kemudian didapatkan nilai standart deviasi sebesar 8 . Untuk mencari batasan nilai 2 kategori, maka nilai terendah dikali dengan jumlah kategori dan kemudian ditambahkan dengan nilai standart deviasi yang didapatkan nilai 38. Penilaian persentase massa lemak tubuh dibagi menjadi 4 kategori berdasarkan Buku Panduan Manual Omron tipe HBF-375 yaitu underfat atau rendah $(<20 \%)$, healthy atau normal $(20-<30 \%)$, overfat atau tinggi $(30-<35 \%)$, dan obese atau sangat tinggi ( $\geq 35 \%$ ). Dari 4 kategori tersebut disederhanakan menjadi 3 kategori yaitu kategori rendah, normal, dan kategori lebih (overfat dan obese). Uji statistik menggunakan uji korelasi chi-square dengan $p<0,05$ untuk menganalisis hubungan antara perilaku diet dengan massa lemak tubuh. Penelitian ini telah memperoleh izin dari Komisi Etik Fakultas Keperawatan Universitas Airlangga dengan No: 1350-KEPK tanggal 1 April 2019.

\section{HASIL DAN PEMBAHASAN}

Distribusi karakteristik responden terdapat pada Tabel 1. Responden penelitian didominasi oleh remaja putri usia 16 tahun sebanyak 59,2\%. Usia merupakan salah satu faktor yang mempengaruhi massa lemak tubuh terutama pada masa remaja ${ }^{15}$. Massa lemak tubuh akan meningkat sejalan dengan bertambahnya usia yang menyebabkan masa remaja rentan terhadap kejadian gizi lebih ${ }^{16}$. Distribusi karakteristik besar uang saku responden didominasi pada rentang Rp. 25.000 - Rp. 75.000 sebanyak 35,5\%. Uang saku dengan nominal yang cukup besar, remaja memiliki kebebasan menggunakan uang tersebut dan cenderung untuk membeli makanan atau minuman yang tanpa disadari dapat mempengaruhi komposisi tubuh ${ }^{17}$. Tidak semua remaja menggunakan uang saku untuk membeli makanan atau minuman yaitu untuk membeli keperluan sekolah (membeli alat tulis, fotocopy, membayar iuran kelas, dan lain-lain) atau ditabung ${ }^{18}$. Distribusi aktivitas fisik responden lebih tinggi pada kategori ringan sebanyak 42,1\%. Kegiatan disekolah menghabiskan waktu yang hampir sama dengan jenis kegiatan yang serupa (homogen) seperti berjalan (berpindah dari satu tempat ke tempat lain), duduk saat kegiatan belajar, berdiri untuk mengerjakan sesuatu di depan kelas, dan lain sebagainya ${ }^{19}$. Distribusi status gizi responden berdasarkan IMT/U sebagian besar tergolong pada kategori normal dengan rentang nilai z-score -2SD sampai dengan 1 SD sebanyak $51,2 \%$. Pada dasarnya IMT/U dapat mencerminkan keseluruhan massa komposisi penyusun tubuh seperti otot, tulang, dan jaringan lemak ${ }^{20}$. IMT/U memiliki nilai sensitivitas yang rendah apabila digunakan sebagai penilaian massa lemak tubuh karena tidak semua individu yang memiliki IMT normal, massa lemak tubuh normal pula ${ }^{21,22}$.

Tabel 1. Distribusi Karakteristik Responden di SMA Negeri 5 Surabaya Tahun 2019

\begin{tabular}{|c|c|c|c|}
\hline \multirow{2}{*}{ Karakteristik } & \multirow{2}{*}{ Rata-rata $\pm S D$} & \multicolumn{2}{|c|}{ Jumlah Responden } \\
\hline & & $\mathrm{N}(76)$ & $\%$ \\
\hline Usia (tahun) & $15,93 \pm 0,639$ & & \\
\hline 15 tahun & & 18 & 23,7 \\
\hline 16 tahun & & 45 & 59,2 \\
\hline 17 tahun & & 13 & 17,1 \\
\hline Besar Uang Saku Harian (Rp) & $22.474 \pm 12.624$ & & \\
\hline$<$ Rp. 15.000 & & 14 & 18,4 \\
\hline Rp. $15.000-<$ Rp. 20.000 & & 16 & 21,1 \\
\hline Rp. $20.000-<$ Rp. 25.000 & & 19 & 25,0 \\
\hline Rp. 25.000 - Rp. 75.000 & & 27 & 35,5 \\
\hline Aktivitas Fisik (METs/minggu) & $2063 \pm 2113$ & & \\
\hline Ringan & $499,45 \pm 92,99$ & 32 & 42,1 \\
\hline Sedang & $1500,57 \pm 845,27$ & 20 & 26,3 \\
\hline Berat & $4616,68 \pm 1864,28$ & 24 & 31,6 \\
\hline Status Gizi (z-score) & $3,11 \pm 0,624$ & & \\
\hline Sangat Kurus & & 2 & 2,6 \\
\hline Kurus & & 2 & 2,6 \\
\hline Normal & & 61 & 80,3 \\
\hline Gemuk & & 8 & 10,5 \\
\hline Obesitas & & 3 & 3,9 \\
\hline
\end{tabular}

Tabel 2 dan 3 distribusi perilaku diet dan 
Terdapat $61,8 \%$ respondentergolong dalam kategori perilaku diet sehat. Berdasarkan hasil kuesioner yang digunakan, perilaku diet sehat yang banyak dilakukan yaitu mengonsumsi air mineral \pm 2 Liter per hari. Dengan mengonsumsi air mineral, lambung akan merasa lebih kenyang sehingga tubuh dapat menolak untuk makan ${ }^{23}$. Kemudian, tidak melewatkan waktu makan dan tetap mengonsumsi snack atau cemilan diluar jam makan utama turut dilakukan dalam perilaku diet sehat. Frekuensi makan diet sehat tetap 3 kali sehari serta diimbangi dengan cemilan diluar jam makan utama berfungsi agar terhindar dari makan dalam jumlah atau porsi banyak dalam satu waktu ${ }^{24}$. Namun terdapat responden yang tergolong dalam kategori perilaku diet tidak sehat yaitu sebesar $38,2 \%$. Perilaku diet tidak sehat

Tabel 2. Distribusi Perilaku Diet Responden di SMA Negeri 5 Surabaya Tahun 2019

\begin{tabular}{|c|c|c|c|}
\hline \multirow[t]{2}{*}{ Perilaku Diet } & \multirow[t]{2}{*}{ Rara-rata $\pm S D$} & \multicolumn{2}{|c|}{$\begin{array}{c}\text { Jumlah } \\
\text { Responden }\end{array}$} \\
\hline & & $\mathbf{N}$ & $\%$ \\
\hline $\begin{array}{l}\text { Diet Sehat (nilai } \\
>38 \text { ) }\end{array}$ & $42,6 \pm 2,44$ & 47 & 61,8 \\
\hline $\begin{array}{l}\text { Diet Tidak Sehat } \\
\text { (nilai } \leq 38)\end{array}$ & $35,5 \pm 2,17$ & 29 & 38,2 \\
\hline Total & $39,8 \pm 4,18$ & 76 & 100,0 \\
\hline
\end{tabular}

Tabel 4 menyajikan data distribusi jumlah responden terkait massa lemak tubuh. Responden dengan jumlah terbanyak ada pada kategori massa lemak tubuh underfat (rendah) yaitu sebesar 35,5\% dengan rata-rata persentase massa lemak tubuh sebesar 18,89\%. Sedangkan untuk kategori massa lemak tubuh healthy (normal) sebesar $32,9 \%$ dengan rata-rata persentase massa lemak tubuh sebesar $24,69 \%$. Akan yang banyak dilakukan yaitu mengurangi berat badan dengan cara berpuasa (di luar waktu ibadah), mengonsumsi obat pelangsing dan pencahar, serta makan dengan cara perlahan-lahan. Menurunkan berat badan dengan cara berpuasa tidak memberikan banyak dampak positif untuk tubuh dalam kurun waktu yang panjang ${ }^{25,26}$. Apabila berpuasa dilakukan dalam waktu yang lama, efek yang akan didapat antara lain gangguan pencernaan (sembelit dan kembung), penurunan metabolisme, serta gangguan pada fungsi kognitif ${ }^{27}$. Lalu diikuti dengan makan secara perlahan selama \pm 20 menit dapat menurunkan nafsu makan yang disebabkan oleh penurunan produksi hormon ghrelin, dimana hormon tersebut merupakan pengatur rasa lapar ${ }^{28}$.

tetapi terdapat pula responden dengan kategori massa lemak tubuh overfat (tinggi) dan obese (sangat tinggi) yaitu masing-masing sebesar $15,8 \%$ dengan rata-rata persentase massa lemak tubuh sebesar $30,26 \%$ dan $35,63 \%$. Apabila kategori massa lemak tubuh overfat dan obese digabung menjadi kategori massa lemak tubuh lebih, didapatkan sebanyak $31,6 \%$ siswi dimana angka tersebut lebih besar dibandingkan penelitian pada remaja putri di SMA Theresiana 1 Semarang yang ditemukan sebanyak $29,0 \%$ responden yang memiliki massa lemak tubuh lebih ${ }^{29}$. Lemak merupakan salah satu sumber energi bagi tubuh yang memiliki peran penting dalam tumbuh kembang remaja ${ }^{30}$. Dengan kondisi lemak dalam tubuh mengalami kekurangan, tubuh akan menggunakan zat gizi lain yaitu protein untuk pembentukan energi. Apabila hal tersebut terjadi dalam jangka waktu panjang, maka akan mengakibatkan terjadinya gangguan kesehatan bagi remaja baik dari segi tumbuh kembang dan psikologis ${ }^{31}$.

Tabel 4. Distribusi Massa Lemak Tubuh Responden di SMA Negeri 5 Surabaya Tahun 2019

\begin{tabular}{lccc}
\hline \multicolumn{1}{c}{ Massa Lemak Tubuh (\%) } & \multirow{2}{*}{ Rata-rata \pm SD } & \multicolumn{2}{c}{ Jumlah Responden } \\
\cline { 3 - 4 } & & $\mathbf{n}$ & $\mathbf{\%}$ \\
\hline Underfat (rendah) & $18,89 \pm 1,58$ & 27 & 35,5 \\
Healthy (normal) & $24,69 \pm 1,15$ & 25 & 32,9 \\
Overfat (tinggi) & $30,26 \pm 0,26$ & 12 & 15,8 \\
Obese (sangat tinggi) & $35,63 \pm 0,66$ & 12 & $\mathbf{1 5 , 8}$ \\
\hline Total & $\mathbf{2 5 , 2 4 \pm 6 , \mathbf { 1 1 }}$ & $\mathbf{7 6}$ & $\mathbf{1 0 0 , 0}$ \\
\hline
\end{tabular}

Tabel 5 menunjukkan responden yang memiliki massa lemak tubuh kategori rendah lebih banyak melakukan diet tidak sehat yaitu sebesar $19,7 \%$. Sedangkan responden dengan massa lemak tubuh kategori lebih dan normal cenderung lebih banyak melakukan diet sehat yaitu sebesar $23,7 \%$ dan $22,4 \%$. Berdasarkan hasil uji statistik menunjukkan nilai $p=0,060$ yang dimana angka tersebut lebih besar dari 0,05. Hal tersebut dapat diartikan bahwa tidak adanya hubungan antara perilaku diet dengan massa lemak tubuh pada responden. Hasil pada penelitian ini tidak sejalan dengan penelitian sebelumnya yang mengemukakan bahwa adanya hubungan antara perilaku diet dengan Indeks Massa Tubuh (IMT), dimana semakin tinggi IMT seseorang maka diet yang dilakukan adalah diet tidak sehat $^{32}$. Namun, penelitian ini sejalan dengan penelitian yang dilakukan di Palembang yang menyatakan bahwa tidak adanya hubungan antara perilaku diet dengan indeks massa tubuh, lingkar perut, dan lingkar lengan atas pada remaja putri.

Perbedaan hasil penelitian ini dapat dikarenakan terdapat faktor lain selain perilaku diet yang dapat menentukan massa lemak tubuh remaja putri, seperti faktor aktivitas fisik dan asupan zat gizi makro. Aktivitas fisik dengan durasi \pm 30 menit dapat membantu pembakaran timbunan lemak dalam tubuh ${ }^{33}$. Selain itu, pengaturan asupan zat gizi makro yang sesuai dengan kebutuhan tubuh akan membantu memperlancar proses metabolisme tubuh sehingga tubuh tidak merasa kekurangan yang dapat menimbulkan tingginya keinginan untuk makan ${ }^{34}$ 
Tabel 3. Distribusi Responden Berdasarkan Kuesioner Perilaku Diet Di SMA Negeri 5 Surabaya

\begin{tabular}{|c|c|c|c|c|c|c|}
\hline \multirow{3}{*}{ Pernyataan } & \multicolumn{4}{|c|}{ Perilaku Diet } & \multicolumn{2}{|c|}{ Total } \\
\hline & \multicolumn{2}{|c|}{ Diet Sehat } & \multicolumn{2}{|c|}{ Diet Tidak Sehat } & \multirow{2}{*}{$\begin{array}{c}n \\
(76)\end{array}$} & \multirow[t]{2}{*}{$\%$} \\
\hline & $\begin{array}{c}n \\
(47)\end{array}$ & $\%$ & n (29) & $\%$ & & \\
\hline \multicolumn{7}{|c|}{ Saya mengurangi porsi makan. } \\
\hline TP & 7 & 9,2 & 10 & 13,2 & 17 & 22,4 \\
\hline KD & 19 & 25,0 & 16 & 21,0 & 35 & 46,0 \\
\hline SR & 11 & 4,4 & 3 & 3,9 & 14 & 18,3 \\
\hline SL & 10 & 13,2 & 0 & 0,0 & 10 & 13,2 \\
\hline \multicolumn{7}{|c|}{ Saya makan 3x sehari dalam porsi setengah dari porsi makan saya biasanya. } \\
\hline TP & 15 & 19,7 & 10 & 13,2 & 25 & 32,9 \\
\hline KD & 15 & 19,7 & 18 & 23,7 & 33 & 43,4 \\
\hline SR & 11 & 14,4 & 1 & 1,3 & 12 & 15,7 \\
\hline SL & 6 & 8,0 & 0 & 0,0 & 6 & 6,8 \\
\hline \multicolumn{7}{|c|}{ Saya mengonsumsi snack atau cemilan diluar jam makan utama. } \\
\hline TP & 0 & 0,0 & 0 & 0,0 & 0 & 0,0 \\
\hline KD & 10 & 13,2 & 9 & 11,9 & 19 & 25,1 \\
\hline SR & 24 & 31,5 & 12 & 15,8 & 36 & 47,3 \\
\hline SL & 13 & 17,1 & 8 & 10,5 & 21 & 27,6 \\
\hline \multicolumn{7}{|c|}{ Saya minum air mineral $\pm 2 \mathrm{~L}$ per hari. } \\
\hline TP & 4 & 5,3 & 1 & 1,3 & 5 & 6,6 \\
\hline$K D$ & 12 & 15,8 & 12 & 15,8 & 24 & 31,6 \\
\hline SR & 9 & 11,8 & 11 & 14,5 & 20 & 26,3 \\
\hline SL & 22 & 28,9 & 5 & 6,6 & 27 & 35,5 \\
\hline \multicolumn{7}{|c|}{ Saya memperhatikan pola makan dan memelihara tubuh dengan latihan fisik. } \\
\hline TP & 8 & 10,5 & 9 & 11,9 & 21 & 22,4 \\
\hline KD & 25 & 32,9 & 15 & 19,7 & 40 & 52,6 \\
\hline SR & 8 & 10,5 & 4 & 5,3 & 12 & 15,8 \\
\hline SL & 6 & 7,9 & 1 & 1,3 & 7 & 9,2 \\
\hline \multicolumn{7}{|c|}{ Saya makan dengan cara perlahan-lahan. } \\
\hline TP & 9 & 11,8 & 7 & 9,2 & 16 & 21,0 \\
\hline KD & 27 & 35,5 & 7 & 9,2 & 34 & 44,7 \\
\hline SR & 6 & 7,9 & 8 & 10,6 & 14 & 18,5 \\
\hline SL & 5 & 6,6 & 7 & 9,2 & 12 & 15,8 \\
\hline \multicolumn{7}{|c|}{ Saya selalu berolahraga dan mengurangi stress. } \\
\hline TP & 12 & 15,8 & 8 & 10,6 & 20 & 26,4 \\
\hline KD & 22 & 28,9 & 16 & 21,0 & 38 & 49,9 \\
\hline SR & 8 & 10,5 & 5 & 6,6 & 13 & 17,1 \\
\hline SL & 5 & 6,6 & 0 & 0,0 & 5 & 6,6 \\
\hline \multicolumn{7}{|c|}{ Saya tidak mengurangi berat badan dengan cara berpuasa (diluar waktu ibadah). } \\
\hline TP & 7 & 9,2 & 20 & 26,3 & 27 & 35,5 \\
\hline KD & 13 & 17,1 & 6 & 8,0 & 19 & 25,1 \\
\hline SR & 10 & 13,2 & 0 & 0,0 & 10 & 13,2 \\
\hline SL & 17 & 22,3 & 3 & 3,9 & 20 & 26,2 \\
\hline
\end{tabular}

Saya tidak mengonsumsi produk pelangsing (WRP, Herbalife, Slimming Tea, dan lain-lain) dan obat pencahar (Dulcolax, Microlax, Laxadine, dan lain-lain).

\begin{tabular}{|c|c|c|c|c|c|c|}
\hline TP & 6 & 7,9 & 18 & 23,7 & 24 & 31,6 \\
\hline$K D$ & 4 & 5,3 & 3 & 4,0 & 7 & 9,3 \\
\hline SR & 1 & 1,3 & 1 & 1,3 & 2 & 2,6 \\
\hline SL & 36 & 47,3 & 7 & 9,2 & 43 & 56,5 \\
\hline \multicolumn{7}{|c|}{ Saya tidak makan malam dan sarapan pagi. } \\
\hline TP & 14 & 18,4 & 11 & 14,5 & 25 & 32,9 \\
\hline KD & 21 & 27,6 & 17 & 22,4 & 38 & 50,0 \\
\hline SR & 10 & 13,2 & 0 & 0,0 & 10 & 13,2 \\
\hline SL & 2 & 2,6 & 1 & 1,3 & 3 & 3,9 \\
\hline \multicolumn{7}{|c|}{ Saya tidak dengan sengaja melewatkan waktu makan. } \\
\hline TP & 5 & 6,6 & 5 & 6,6 & 10 & 13,2 \\
\hline KD & 12 & 15,8 & 15 & 19,8 & 27 & 35,6 \\
\hline SR & 26 & 34,2 & 5 & 6,6 & 31 & 40,8 \\
\hline SL & 4 & 5,2 & 4 & 5,2 & 8 & 10,4 \\
\hline
\end{tabular}

Saya tidak makan banyak pada satu waktu. 


\begin{tabular}{|c|c|c|c|c|c|c|c|}
\hline TP & & & 0,0 & 2 & 2,6 & 2 & 2,6 \\
\hline KD & & & 19,7 & 18 & 23,7 & 33 & 43,4 \\
\hline SR & & & 23,7 & 6 & 7,9 & 24 & 31,6 \\
\hline \multirow{2}{*}{ SL } & & & 18,4 & 3 & 4,0 & 17 & 22,4 \\
\hline & $\mathbf{n}$ & $\%$ & $\mathbf{n}$ & $\%$ & & & \\
\hline \multicolumn{8}{|c|}{ Saya tidak memuntahkan makanan yang saya makan. } \\
\hline TP & 0 & 0,0 & 2 & 2,7 & 2 & & 2,7 \\
\hline KD & 1 & 1,3 & 0 & 0,0 & 1 & & 1,3 \\
\hline SR & 0 & 0,0 & 8 & 10,5 & 8 & & 10,5 \\
\hline SL & 46 & 60,5 & 19 & 25,0 & 65 & & 85,5 \\
\hline \multicolumn{8}{|c|}{ Saya tidak merokok. } \\
\hline TP & 0 & 0,0 & 0 & 0,0 & 0 & & 0,0 \\
\hline KD & 0 & 0,0 & 0 & 0,0 & 0 & & 0,0 \\
\hline SR & 0 & 0,0 & 0 & 0,0 & 0 & & 0,0 \\
\hline SL & 47 & 61,8 & 29 & 38,2 & 76 & & 100,0 \\
\hline Total & 47 & 61,8 & 29 & 38,2 & 76 & & 100,0 \\
\hline
\end{tabular}

Keterangan: TP=Tidak Pernah, KD= Kadang-Kadang, $S R=S e r i n g, ~ S L=S e l a l u$

Penelitian ini meneliti perilaku diet dan hubungannya dengan massa lemak tubuh namun belum menganalisis variabel lain seperti jenis diet yang dilakukan serta kondisi emosional pada saat melakukan diet dan hubungannya dengan massa lemak tubuh remaja. Sehingga diperlukan penelitian lanjutan mengenai hal tersebut dengan massa lemak tubuh remaja.

Tabel 5. Hubungan Perilaku Diet dengan Massa Lemak Tubuh Responden di SMA Negeri 5 Surabaya Tahun 2019

\begin{tabular}{|c|c|c|c|c|c|c|c|c|c|}
\hline \multirow{3}{*}{ Perilaku Diet } & \multicolumn{6}{|c|}{ Massa Lemak Tubuh } & \multicolumn{2}{|c|}{ Total } & \multirow[t]{3}{*}{ Nilai p } \\
\hline & \multicolumn{2}{|c|}{ Rendah } & \multicolumn{2}{|c|}{ Normal } & \multicolumn{2}{|c|}{ Lebih } & \multirow{2}{*}{$\mathbf{n}$} & \multirow{2}{*}{$\%$} & \\
\hline & $\mathbf{n}$ & $\%$ & $\mathrm{n}$ & $\%$ & $\mathbf{n}$ & $\%$ & & & \\
\hline Diet Sehat & 12 & 15,8 & 17 & 22,4 & 18 & 23,7 & 47 & 61,8 & \multirow{3}{*}{0,060} \\
\hline Diet Tidak Sehat & 15 & 19,7 & 8 & 10,5 & 6 & 7,9 & 29 & 38,2 & \\
\hline Total & 27 & 35,5 & 25 & 32,9 & 24 & 31,6 & 76 & 100,0 & \\
\hline
\end{tabular}

\section{KESIMPULAN}

Pada penelitian ini menunjukkan tidak adanya hubungan antara perilaku diet dengan massa lemak tubuh pada remaja putri di SMA Negeri 5 Surabaya. Maka diperlukan penelitian lebih lanjut untuk menganalisis faktor lain yang berhubungan dengan perilaku diet dan massa lemak tubuh pada remaja putri.

\section{ACKNOWLEDGEMENT}

Penulis berterima kasih kepada seluruh responden penelitian, Badan Kesatuan Bangsa dan Politik Kota Surabaya, Dinas Pendidikan Kota Surabaya, SMA Negeri 5 Surabaya yang telah memberikan ijin dan membantu berjalannya proses penelitian ini, Dosen Program Studi Gizi Fakultas Kesehatan Masyarakat Universitas Airlangga serta staff, terkhusus kepada dosen pembimbing sehingga terselesaikannya penelitian ini.

\section{REFERENSI}

1. Krori, S. D. Developmental Psychology. Homeopath. J. 4, (2011).

2. Santrock, J. W. Adolescence: Perkembangan Remaja. (Erlangga, 2003).

3. World Health Organization. Strategic Action Plan to reduce the double burden of in the. (2016).

4. Carroll, M. D., Navaneelan, T., Bryan, S. \& Ogden, C. L. Prevalence Of Obesity Among Children And Adolescents In The United States And Canada. NCHS Data Brief (2015).

5. Badan Penelitian Dan Pengembangan
Kesehatan Kementerian Kesehatan RI. RISET KESEHATAN DASAR RISKESDAS 2010. (2010).

6. Badan Penelitian Dan Pengembangan Kesehatan Kementerian Kesehatan RI. Hasil Riskesdas 2013.

7. Dinas Kesehatan Provinsi Jawa Timur. Profil Kesehatan Jawa Timur. Surabaya. (2016).

8. Widianti, N. HUBUNGAN ANTARA BODY IMAGE DAN PERILAKU MAKAN DENGAN STATUS GIZI REMAJA PUTRI DI SMA THERESIANA SEMARANG. (Diponegoro University, 2012).

9. Mendes, V., Araújo, J., Lopes, C. \& Ramos, E. Determinants of Weight Loss Dieting Among Adolescents: A Longitudinal Analysis. J. Adolesc. Heal. 54, 360-363 (2014).

10. Haynos, A. F., Field, A. E., Wilfley, D. E. \& Tanofsky-Kraff, M. A novel classification paradigm for understanding the positive and negative outcomes associated with dieting. Int. J. Eat. Disord. 48, 362-366 (2015).

11. Murray, R. K., Granner, D. K. \& Rodwell, V. W. Biokimia Harper. in (EGC, 2009).

12. Mani, B. K. \& Zigman, J. M. Ghrelin as a Survival Hormone. Trends in Endocrinology and Metabolism vol. 28 843-854 (2017).

13. Kemenkes. Standar Antropometri Penilaian Status Gizi Anak. (2010).

14. Sundari, V. Hubungan Antara Rasa Percaya Diri Dengan Perilaku Diet Pada Remaja Putri. (Universitas Muhammadiyah Malang, 2012).

15. Ducharne, J. \& Forest, M. Normal Pubertal 
Development. in Pediatric Endocrinology 372386 (1993).

16. Schmidt, S. C., Bosy-Westphal, A., Niessner, C. \& Woll, A. Representative body composition percentiles from bioelectrical impedance analyses among children and adolescents. The MoMo study. Clin. Nutr. (2018)

doi:10.1016/J.CLNU.2018.11.026.

17. Aini, S. N. Faktor Risiko Yang Berhubungan Dengan Kejadian Status Gizi Lebuh Pada Remaja Di Perkotaan. Unnes Journal of Public Health vol. 2

http://journal.unnes.ac.id/sju/index.php/ujph (2013).

18. Oktaviani, W. D., Saraswati, L. D. \& Rahfiludin, M. Z. HUBUNGAN KEBIASAAN KONSUMSI FAST FOOD, AKTIVITAS FISIK, POLA KONSUMSI, KARAKTERISTIK REMAJA DAN ORANG TUA DENGAN INDEKS MASSA TUBUH (IMT) (Studi Kasus pada Siswa SMA Negeri 9 Semarang Tahun 2012). Undip E-Journal 1, 542-553 (2012).

19. Hafid, F., Cahyani, Y. \& Ansar, A. AKTIVITAS FISIK, KONSUMSI MAKANAN CEPAT SAJI DAN KOMPOSISI LEMAK TUBUH REMAJA SMA KARUNA DIPA PALU . Promot. J. Kesehat. Masy. 8, (2018).

20. Stang, J. \& Story, M. Guidelines for Adolescent Nutrition Services. in (2005).

21. Nuttall, F. Q. Body mass index: Obesity, BMI, and health: A critical review. Nutr. Today 50, 117-128 (2015).

22. Widyastuti, R. A. \& Rosidi, A. Indeks Massa Tubuh Menurut Umur sebagai Indikator Persen Lemak Tubuh pada Remaja. J. Gizi 32-39 (2017).

23. Chaenurisah, L., Syamsianah, A. \& Su, Y. N. Perbedaan Penurunan Berat Badan Berdasarkan Ketaatan Pelaku Diet Kombinasi Makanan Serasi (Food Combining) di Komunitas 'Qita Sehat Dengan FC' di Kota Semarang.

24. Rahmadani, P. A. . HUBUNGAN CITRA TUBUH TERHADAP PERILAKU DIET PADA REMAJA
PUTRI. (STIKES Insan Cendekia Media Jombang, 2017).

25. Alhamdan, B. A. et al. Alternate-day versus daily energy restriction diets: which is more effective for weight loss? A systematic review and metaanalysis. Obes. Sci. Pract. 2, 293-302 (2016).

26. Harris, L. et al. Intermittent fasting interventions for treatment of overweight and obesity in adults: a systematic review and metaanalysis. Jbi Database Syst. Rev. Implement. Reports 16, 507-547 (2018).

27. Yannakoulia, M., Poulimeneas, D., Mamalaki, E. \& Anastasiou, C. A. Dietary modifications for weight loss and weight loss maintenance. Metab. - Clin. Exp. 92, 153-162 (2019).

28. Hurst, Y. \& Fukuda, H. Effects of changes in eating speed on obesity in patients with diabetes: A secondary analysis of longitudinal health check-up data. BMJ Open 8, (2018).

29. Widyaningtyas, S. . HUBUNGAN USIA MENARCHE DENGAN OBESITAS PADA REMAJA PUTRI DI SMA THERESIANA 1 SEMARANG. (Diponegoro University, 2012).

30. Batubara, J. R. Adolescent Development (Perkembangan Remaja). Sari Pediatr. 12, (2010).

31. Adriani, M. \& Wirjatmadi, B. Zat Gizi Yang Berkaitan Dengan Obesitas. in Pengantar Gizi Masyarakat (Kencana Prenada Media Grup, 2012).

32. Pratama, Y. Hubungan Antara Indeks Massa Tubuh (IMT) Dengan Perilaku Diet Remaja Putri. (Muhammadiyah University Malang, 2012).

33. Kerksick, C. M. et al. Changes in weight loss, body composition and cardiovascular disease risk after altering macronutrient distributions during a regular exercise program in obese women. Nutr. J. 9, (2010).

34. Morenga, L. Te \& Montez, J. M. Health effects of saturated and trans-fatty acid intake in children and adolescents: Systematic review and metaanalysis. PLOS ONE vol. 12 (2017). 